\title{
Meta-analysis of the effect of psychological nervous interventions on improving academic performance in students with specific learning disabilities
}

\author{
Azam Rashidi ${ }^{1}$, Salar Faramarzi ${ }^{2}$, Abdolhossein Shamsi ${ }^{3}$ \\ 1-PhD. Student, Department of Psychology and Education of Children with Special Needs, University of Isfahan, \\ Isfahan, Iran (Corresponding Author). $\quad$ E-mail: aa.rashidi391@Yahoo.com \\ 2- Associate Professor, Department of Psychology and Education of Children with Special Needs, University of \\ Isfahan, Isfahan, Iran. \\ 3- PhD. Student, Department of Psychology and Education of Children with Special Needs, University of Isfahan, \\ Isfahan, Iran.
}

Received: 19/10/2019

Accepted: 25/01/2020

\begin{abstract}
Introduction: Learning disabilities is one of the neuropsychological disorders that refers to delay and decrease in students' performance in some subjects, such as arithmetic, reading, writing, spelling and speaking, therefore they create a significant gap between students' potential and actual performance.
\end{abstract}

Aim: The aim of this study has been meta-analysis of the effect of psychological nervous interventions on improving academic performance in students with specific learning disabilities.

Method: This study has been performed by the meta-analysis method. The statistical population includes dissertations and researches published in scientific-research journals that have been done over the past 10 years (2009-2018) in the field of neuropsychological interventions to improve the academic performance in students with learning disabilities in Iran. Sample size was out of 36 studies which 24 methodologically that they were acceptable and the meta-analysis has been performed on them. The research tool is the meta-analysis checklist.

Results: These researches were based on 695 samples and 24 effect sizes. The findings showed, the effect size of the nervous interventions on academic performance improving in students with specific learning disabilities was $d=1.58(\mathrm{p}=0.001)$. According to Cohen's table this effect size is high.

Conclusion: The results indicated that these neuropsychological interventions have had a great effect on improving students' academic performance with specific learning disabilities. Furthermore, it is recommended for the experts to use these interventions on improving academic performance on these students. Moreover, based on different therapeutic approaches, it is important to consider the cultural context in different societies.

Keywords: Psychological nervous, Interventions, Specific learning disabilities, Meta-analysis

How to cite this article : Rashidi A, Faramarzi S, Shamsi A. Meta-analysis of the effect of psychological nervous interventions on improving academic performance in students with specific learning disabilities. Shenakht Journal of Psychology and Psychiatry. 2020; 6 (6): 125-140 . URL: http://shenakht.muk.ac.ir/article-1-708-fa.pdf

Copyright (C) 2018 the Author (s). Published by Kurdistan University of Medical Sciences. This is an open access article distributed under the terms of the Creative Commons Attribution-Non Commercial License 4.0 (CCBY-NC), where it is permissible to download, share, remix, transform, and buildup the work provided it is properly cited. The work cannot be used commercially without permission from the journal. 


\title{
فرا تحليل اثربخشى مداخلات عصب روانشناختى بر بهبود عملكرد تحصيلى داش آموزان با اختلالات يادكيرى ويثر مدانه
}

\author{
اعظم رشيدى'، سالار فرامرزى ‘ عبدالحسين شمسى \\ ا.دانشجوى دكترى، گروه روان شناسى و آموزش كود كان با نيازهاى خاص، دانشكاه اصفهان، اصفهان، ايران (مولف مسئول). \\ ايميل: إد :Yahoo.com

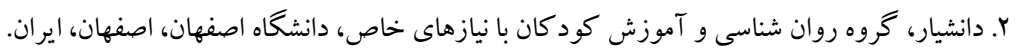

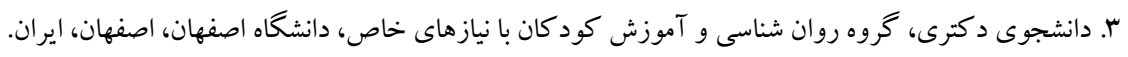

مقدمه: اختلالات ياد گيرى يكى از اختلالات عصب روانشناختى است كه به تأخير و كاهش عملكرد دانش آموزان در برخى دروس،

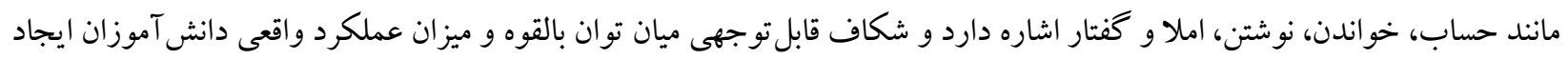
مى كند. هدف: هدف از يثزوهش حاضر فراتحليل اثربخشى مداخلات عصب روانشناختى بر بهبود عملكرد تحصيلى دانش آموزان با اختلالات ياد كيرى ويزه بود.

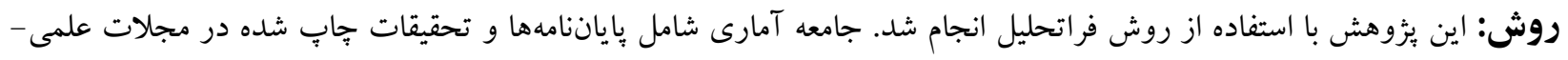

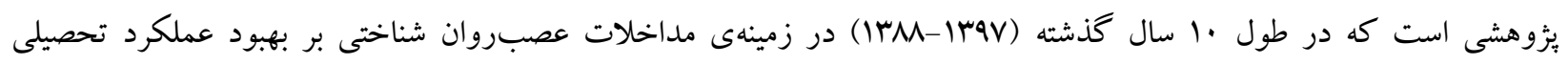

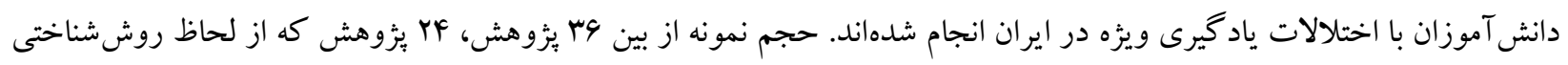

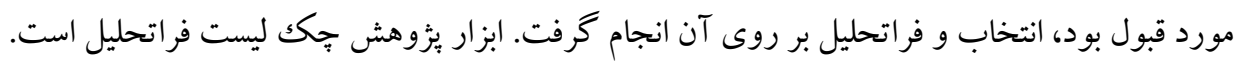

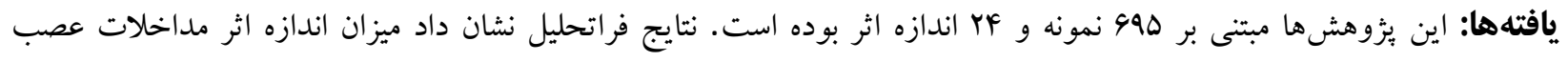

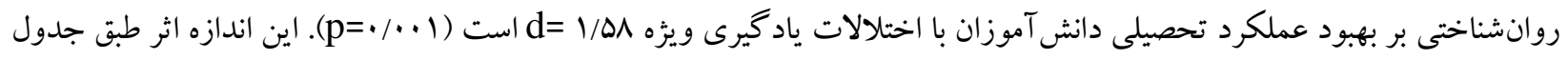
كوهن بالا است. نتيجه كيرى: نتايج حاكى از آن بود كه اين مداخلات عصب روانشناختى بر بهبود عملكرد تحصيلى دانش آموزان با اختلالات

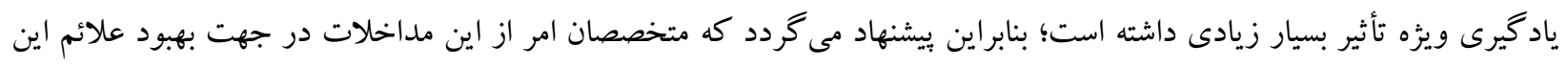

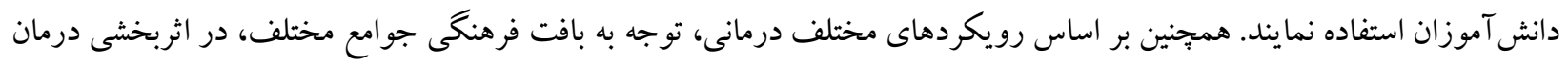

حائز اهميت است. كليد وازهها: مداخلات عصب روانشناختى، اختلالات يادگيرى ويزه، فراتحليل 
شنيدن، انديشيدن، حرف زدن، خواندن، نوشتن، هجى كردن و يا محاسبات رياضى بروز دهد (كارسيا، بريرا و

$$
\text { فاكودا }
$$

با وجود اينكه علل فراوانى براى ناتوانى يادگيرى وجود دارد و عليرغم ارزيابى جامع، اما هنوز علت آن ناشناخته

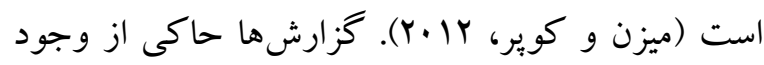
يكك عامل زنتيكى در تعداد قابل توجهى از كودكان با ناتوانى در يادگيرى است (فاستر، تيدراج و مورتون؛ ها +r). علاوه بر آن تحقيقات نشان مىدهند كه عوامل عصب روانشناختى در ايجاد اين مشكلات دخالت دارند. بثزوهشكران بيشنهاد كردهاند كه براى بهبود عملكرد تحصيلى در اين كود كان، بايد مداخلات خاصى متناسب با مشكل عصب روانشناختى اعمال نمود (شالو، آربج،

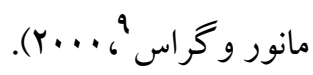

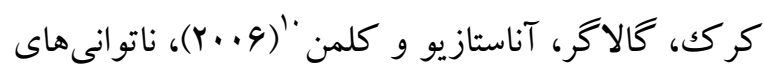
يادگيرى را در سه حيطه ناتوانى يادگيرى عصب

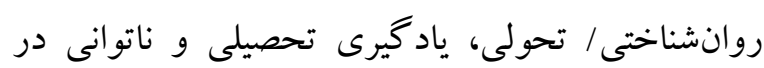
مهارتهاى اجتماعى طبقهبندى كردهاند. آنان معتقدند كه ناتوانىهاى يادگيرى عصبروان شناختى/ تحولى آى

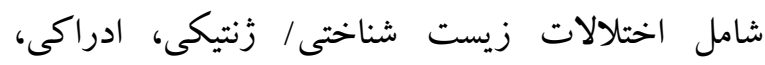
حر كتى، اختلال در بردازش بينايى "و شنوايى "َ'، اختلال

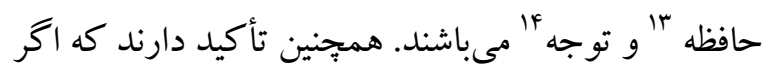
ناتوانى هاى يادگيرى عصب روانشناختى/ تحولى بيش از دبستان به موقع شناسايى و درمان نشوند، به ناتوانى ياد گيرى تحصيلى (اختلال خو اندن، ديكته و رياضى) در مقلdمه

اختلالات ياد گيرى كلى'، با مشكلات وسيع در انواع مهارتهاى تحصيلى مشخص مىشود، در حالى كه

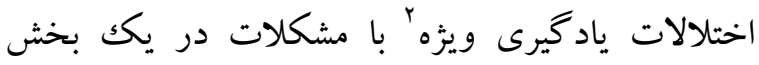
خاص از مهارتهاى تحصيلى مشخص مىشود (هولم و

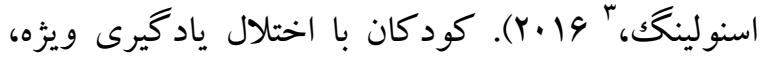
اغلب از نظر ذهنى داراى نقاط ضعف و قوت مشخص مىباشند (كورنولدى، ديكايريو، فرانسيسكو، توفالينى'،

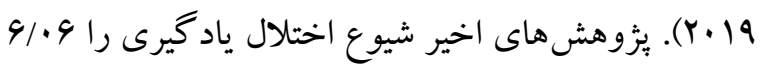
در صد بر آورد مى كنند (كايا، گيليويب، اسكيليروك،

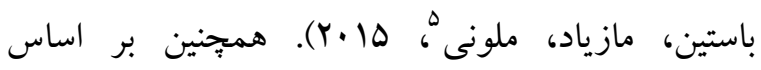
راهنماى تشخيصى و آمارى اختلالهاى روانى، ناتوانى ياد گيرى در طبقه اختلالات عصبى- تحولى قرار دارد كه با شيوع ها تا ها درصد، مهمترين علت عملكرد ضعيف

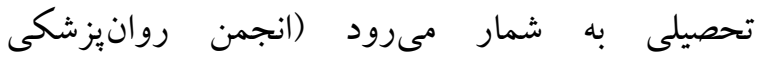

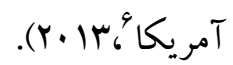
ويز گیى برجسته اين گروه از دانش آموزان، اختلال در يكك يا جند فرايند روانشناختى پايه است كه موجب

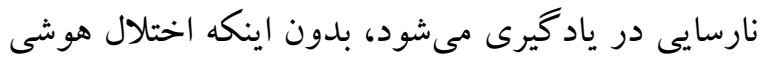
و يا حسى در آنها وجود داشته باشد؛ بنابراين در تعريف اختلال يادگيرى مىتوان گفت كه فرد با وجود سن كافى، امكانات و آموزش مناسب، عدم وجود مشكلات حسى، نداشتن آسيبهاى جدى مغزى، هوشى و هيجانى، در يادگيرى مهارتهاى تحصيلى پايه دجار مشكلات

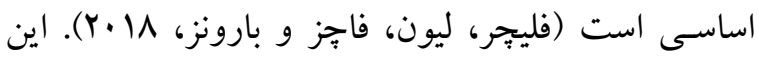
ناتوانى ممكن است خودش را بهصورت نقص در توانايى

\footnotetext{
7. Garcia, Pereira \& Fukuda

8 - Foster, Titheradge \& Morton

${ }^{9}$ - Shalev, Auerbach, Manor\& Gross Tsur

${ }^{10}$ - Kirk, Gallagher, Anastasiow\& Coleman

${ }^{11}$ - Visual Processing Disorders

${ }^{12}$ - Auditory Processing Disorders

${ }^{13}$ - Memory Disorders

${ }^{14}$ - Attention Disorders
}

\footnotetext{
1. General Learning Disorders

${ }^{2}$ - Specific Learning Disabilities

${ }^{3}$ - Hulme \& Snow

4- Cornoldi, Di Caprio, De Francesco \& Toffalini.

5 - Cappaa, Giulivib, Schiliròc, Bastiania, Muziod \& Meloni

${ }^{6}$ - American Psychiatric Association (APA)
} 
مهارتهاى زبان، يردازش بينايى-فضايى و حافظه فعال) بر بهبود عملكرد تحصيلى كودكان داراى ناتوانى ياد گيرى اشاره كردهاند.

با توجه به اهميت مهارت هاى عصب روانشناختى ونيز

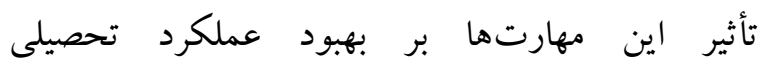
دانشآموزان با اختلالات يادكيرى، يثوهشهاى زيادى در اين زمينه در كشور انجام شده است كه مىتوان به

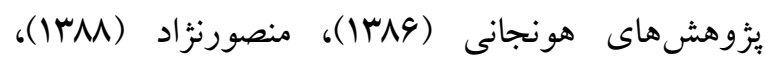
خدامى، عابدى و آتش :يور (1) (1)، عابدى وآقابابايى

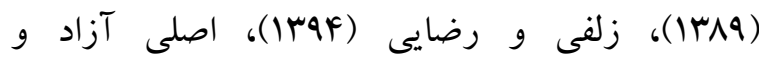

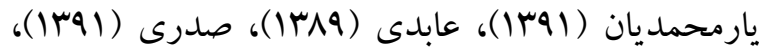
نيكومحمدى، عليزاده، كريمى، حكيمىراد و امين آبادى

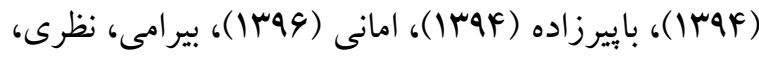
هاشمى و موحدى (هوب())، اصلى آزاد، عابدى و

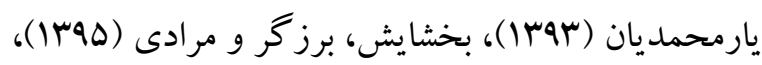
قلمزن، ملكك بور و فرامرزى (سوسו)، مسعودى (سوسا)،

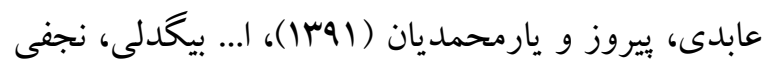

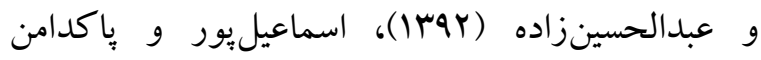

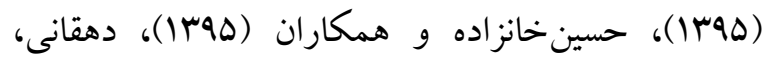

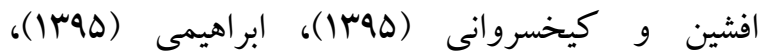
محموديور (هوبr)، محمدى، اقبالى، محمدى وكريمى (ولى

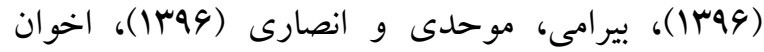
تفتى، رباطجزى و هاشمى (4) (I) اشاره نمود. با توجه به اينكه بزّوهشهاى زيادى با محوريت مداخلات مبتنى بر مهارتهاى عصب روانشناختى در زمينه بهبود عملكرد تحصيلى دانش آموزان با اختلالات يادگيرى ويزه، در ايران انجام شده است، ضرورت مى يابد تا در جهار جوب انجام يكك فرا تحليل به اين سؤال ياسخ داد كه از بين اين مداخلات، كدام يكك از برنامهها
دبستان منجر خواهد شد و يا به صورت ناتوانى در مهارتهاى اجتماعى (خودينداره و اعتماد به نفس بايين، انكيزه و علاقه بايين و رفتار مقابلهاى) خود را نشان مىدهد. لذا براى اينكه اين كودكان مهارتهاى اوليه لازم براى موفقيت در يادگيرى تحصيلى را فرا بخيرند، نيازمند تشخيص و مداخله زودهنگام هستند (عابدى، لراي،

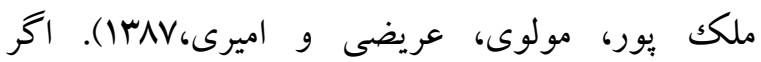
اختلالات يادگيرى تحصيلى در دانشآموزان درمان نشود، به اختلالات ياد گيرى اجتماعى در دورههاى بعدى يحى لئى زندگىشان تبديل مى شود و بر عكس اخر بهبود يافته و توسط افراد مديريت كردد، مشكلى در آينده فرد ايجاد نمى كند و جهه بسا فرد به درجات عالى علمى دست يابند

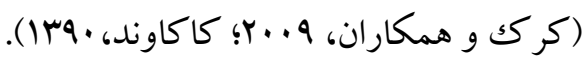
در سبب شناسى، طراحى و تهيه مداخلات آموزشى، توجه به ويز گیىا و نيم رخ عصب روانشناختى اين دانش آموزان بسيار اهميت دارد، از اين رو در سال هاى اخير درباره ويز گى هاى عصب روان شناختى كود كان با بان ناتوانى ياد گيرى مطالعات بسيارى انجام شده است. مطالعات مؤمنى، ملكك يور، عابدى و فرامرزى (I IVQV)، رهبر، ابوالقاسمى، حسين خانزاده و رهبر (IMQV)،

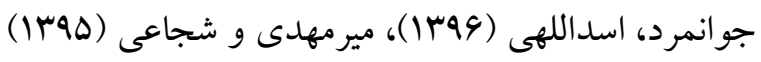
نشان داد كه كودكان با ناتوانايى يادگيرى در جنبههاى عصب روانشناختى (كاركردهاى اجرايى، توجه، زبان، بردازش بينايى-فضايى، حافظه و ياد كيرى) مشكل دارند. تعدادى از يزوهشخران از جمله سوانسون، هاوارد،

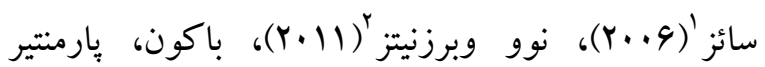

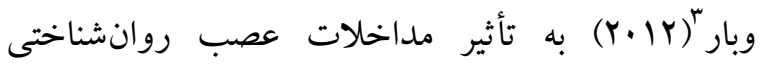
(آموزش و تقويت كاركردهاى اجرايى، توجه،

\footnotetext{
1- Swanson, Howard \& Saez

2- Nevo, \& Breznitz

3 - Bacon, Parmentier \& Barr
} 
لازم از نظر روش شناسى (فرضيه سازى، روش تحقيق،

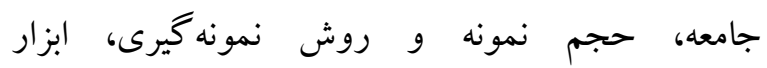

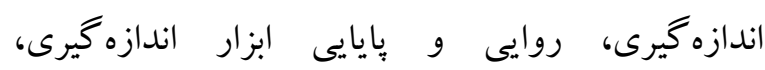
مفروضههاى آمارى، روش تحليل آمارى و صحيح بودن إنياني

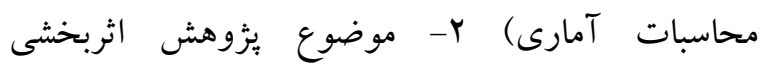
مداخلات عصب روانشناختى (آموزش و وتقويت كاركردهاى اجرايى، توجه، مهارتهاى زبان، بردازش بينايى-فضايى و حافظه فعال) بر بهبود عملكرد تحصيلى

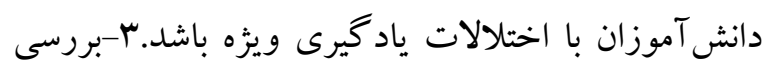
در قالب يك بثزوهش گروهى صورت كرفته باشد (موردى و آزمون منفرد نباشد)F-تحقيقات بهصورت

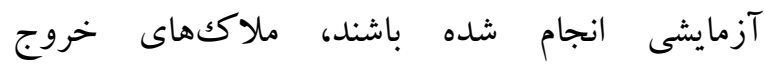
يُخوهشهايى بودند كه شرايط روش شناسى را نداشتند و يا بهصورت موردى، مرورى، همبستكى و توصيفى انجام

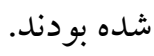

ابزار جك ليست فراتحليل (از لحاظ روش شناختى): ابزار اين يثزوهش جُك ليست فراتحليل (از لحاظ روش شناختى) بود. از اين جّك ليست به عنوان ابزارى براى انتخاب باياننامهها و مقالههاى بزّوهشى داراى ملاككهاى "ادرون كنجى" و استخراج اطلاعات لازم براى انجام فراتحليل

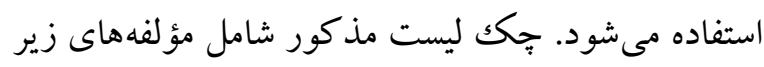
بود: عنوان بثزوهشهاى انجام شده كه تنها دربارهى بهبود عملكرد تحصيلى دانش آموزان با اختلال يادگيرى ويزه باشد، مشخصات كامل مجريان، سال اجراى يزوهش، روايى و اعتبار آنها، ابزارهاى جمع آورى اطلاعات، جامعه آمارى، حجم نمونه و سطح معنادارى آزمونها بكار گرفته شده. لازم به ذكر است روايى محتوى اين جִك ليست توسط جند متخصص آمارى و روانشناسى
بيشترين تأثير و كار آمدى را داشته است تا به واسطه اين يافته گامى در جهت راهنمايى مربيان، معلمان، مشاوران و روانشناسان حوزه اختلالات يادگيرى ويزه برداشته شود.

روش در اين تحقيق با توجه به هدف يثوهش از روش (فراتحليل) استفاده شد. در روش فراتحليل اصل اساسى

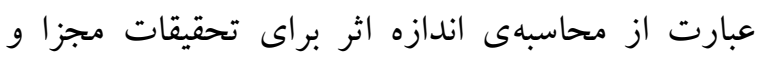
بر گرداندن آنها به يكك ماتريس مشترك (عمومى) و و آنگاه تر كيب آنها براى دستيابى به ميانگين تأثير است.

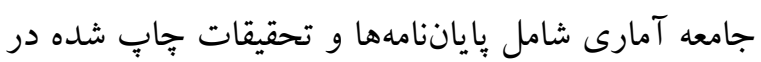
مجلات علمى - بزوهشى بودند كه در طول •1 سال كذشته (IMqV-IM شناختى بر بهبود عملكرد تحصيلى دانش آموزان با اختلالات ياد گيرى ويزه در ايران انجام شدهاند كه حجم بـم نمونهى مناسبى داشته و از لحاظ روششناسى (فرضيه سازى، روش تحقيق، جامعه، حجم نمونه و روش نمونه گيرى، ابزار اندازهيرى، روايى و و بايايى ابزار اندازه گيرى، فرضيههاى آمارى، روش تحليل آمارى و صحيح بودن محاسبات آمارى) شرايط لازم را داشتهاند. اين بررسى براى هر MF منبع مورد استفاده در فراتحليل انجام شد. منابع مورد جستجو در يُزوهش حاضر شامل برل باياننامههاى كارشناسى ارشد و دكترى دانشگاههاى مختلف (مراجعه يثوهشخر به كتابخانه دانشگاه)، مجلات علمى-يثوهشى در حوزه روانشناسى و علوم تربيتى، همايشهاى داخلى، بانكى منابع اطلاعاتى رهاد دانشگاهى، مركز اسناد ايران است. فقط منابع فارسى و تحقيقاتى كه در ايران انجام شدند مورد بررسى قرار

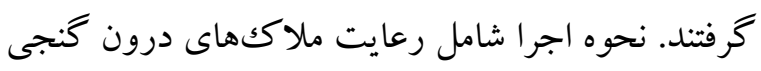
براى فراتحليل بود كه عبارتاند از: ا- داشتن شرايط 
يكك از بزؤهشها با دقت و بهصورت دستى محاسبه شده است. به همين منظور ابتدا بايد آنجه اندازه اثر ناميده مىشود را در هر يكك از بثزوهشها به صورت جداگانه محاسبه كرد. اندازه اثر، بيانكر تفاوت استاندارد شده بين

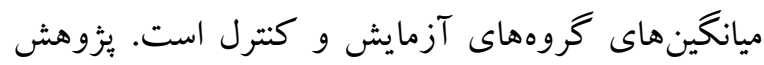
هاى مورد استفاده در بزظوهش به تفكيك مشخصات آن در جدول ا گززارش شده است.
مورد ارزيابى قرار گرفت. ضريب CVI و CVR بيانكر رعايت روايى محتواى اين جّك ليست بود.

\section{يافته ها}

در اين ئزوهش شيوه محاسباتى فراتحليل، بر اساس مراحل فراتحليل كوهن انجام شده است. در روش فراتحليل جهار گام اساسى بايد برداشته شود: شناسايى، انتخاب، انتزاع و تجزيه و تحليل. براى به دست آوردن ميزان اندازه اثر از نرم افزارى استفاده نشده و اندازه اثر هر

جدول ا دادههاى مطالعات مختلف درباره اثربخشى مداخلات عصب روانشناختى بر بهبود عملكرد تحصيلى

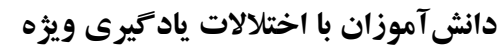

\begin{tabular}{|c|c|c|c|c|c|c|c|c|}
\hline Tاره & جنسيت & يِيكيرى & اجران & طول & آزمودنى سن & يخوهشكر (ان) & نوع مداخله & 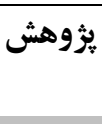 \\
\hline كوواريانس & دختر & خير & مياندو آب & ال & $9-1$. & زلفى، رضايى (FaF) & مداخله رايانه يار حافظه & 1 \\
\hline كوواريانس & دختر & خير & اصفهان & 11 11 جلسه 9 دقيقهاى & $9-11$ & خدامى، عابدى، & $\begin{array}{c}\text { آموزش كاركردهاى اجرايى } \\
\text { آيى }\end{array}$ & $r$ \\
\hline كوواريانس & 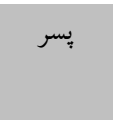 & خير & اصفهان & ه 10 جلسه 9 دقيقهاى & $\wedge-1$ & 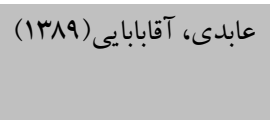 & آموزش حافظه فعال & $r$ \\
\hline كوواريانس تحليل & دختر و & خير & اصفهان & 4 Y Y جلسه & $1 \cdot-9$ & يارمحلى آزاد و & آموزش فراشناخت و & p \\
\hline كوواريانس & دختر و & خير & اصفهان & $\begin{array}{l}9 \text { PF } \\
\text { دقيقهاى FF }\end{array}$ & $9-1$. & عابدى( & مداخلات عصب روانشناختى & $\Delta$ \\
\hline كوواريانس & دختر و & خير & بير جند & 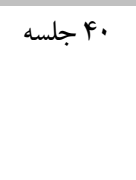 & $9-11$ & نيكو محمدى، عليز اده، & 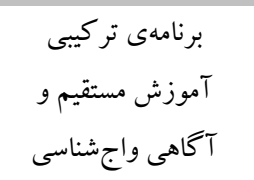 & 9 \\
\hline كوواريانس & دختر و & خير & 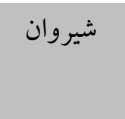 & كا rا جلسه & $\wedge-11$ & امانى(1r99) & تقويت كاركردهاى & v \\
\hline كوواريانس & دختر و & خير & ت ير يز & 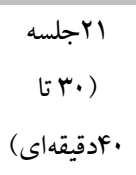 & $\wedge-11$ & بيرامى، نظرى، هاشمى، & نوروسايكولوزيكى & $\wedge$ \\
\hline كوواريانس تحليل & دخر & خير & اصفهان & با بلسه & $9-1$. & 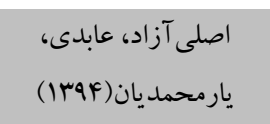 & آموزش دركى روابط & 9 \\
\hline تحليل & ֵֶ & خير & 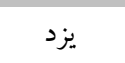 & 11 ا جلسه & $9-1$. & بخشايش، برزگر، & آموزش حافظه كارى & $1 \cdot$ \\
\hline
\end{tabular}




\begin{tabular}{|c|c|c|c|c|c|c|c|c|}
\hline كوواريانس & & & & له دقيقهاى & & بفرويى، مرادى عجىى(هوسا) & & \\
\hline كوواريانس & پֶر & خير & اصفهان & | & $\Delta-9$ & 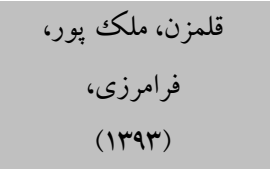 & باز ىهاى توجهى & 11 \\
\hline كوواريانس & دختر & خير & اصفهان & 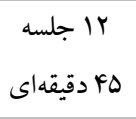 & $9-1$. & عابدى، بيروز زيجردى، & آموزش توجه & ir \\
\hline t t t t t t t & دخر و & خير & حيدريت & ^ جلسه & v & ا...بيخدلى، نجفى، & كاربرد ياديارها & Ir \\
\hline كوواريانس & دختر و & خير & كرمانشاه & . & $9-11$ & وهمكار ان( حهانز اده & 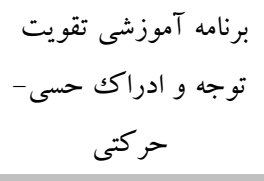 & if \\
\hline كوواريانس & دخر و & خير & كرمانشاه & ^ جلسه & $9-1$ & محمدى، اقبالى، متعالى، & ور روش گلينگهام -وروتون & 10 \\
\hline كوواريانس & دختر و دِ & خير & 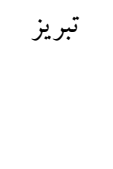 & 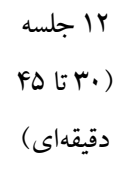 & $\wedge-11$ & بيرامى، نظرى، هاشمى، & توروسايكولوزيكى - نو & 19 \\
\hline كوواريانس & دختر و & خير & بوشهر & ها 10 د جلسه & $11-14$ & كهقانى، افشين، & دروان عصب & iv \\
\hline كوواريانس & دختر و & خير & 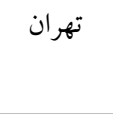 & 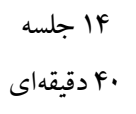 & $9-1$. & اخوان تفتى، رباط جزى، & بازىهاى توجه افزا & 11 \\
\hline كوواريانس & دختر و دِر & خير & ذهريل & . & $9-1$. & بإيرزاده(IFqF) & 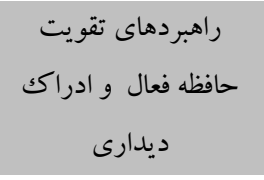 & 19 \\
\hline كوواريانس & دختر & بله & اصفهان & • & $V-9$ & صدرى(|qr|) & مداخلات عصب روانشناختى & $r \cdot$ \\
\hline كوواريانس & دخر و & خير & 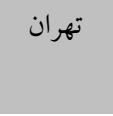 & 9 9 دقيقهاى جلسه & $\wedge-1$ & آزيتا محموديور (هوسו) & $\begin{array}{c}\text { برنامه آموزش مهارهاى } \\
\text { توجه }\end{array}$ & rI \\
\hline كوواريانس & دختر و & خير & 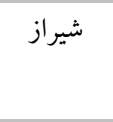 & 1 1 جلسه & $\wedge-1$ & مسعودى(سهr|) & 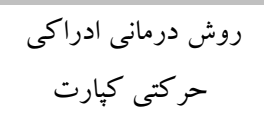 & rr \\
\hline كوواريانس & دختر و & خير & اصفهان & ه 10 جلسه 9 دقيقهاى & $9-1$. & هونجانى(1ra9) & آموزش دقت & r r \\
\hline كوواريانس & دختر و & خير & كاشان & ال اجلسه & $1-9$ & منصورنزاد(IMMA) & روش جنّد حسى فرنالد & pr \\
\hline
\end{tabular}


نيز مربوط به يُوهش نيكو محمدى، عليزاده، كريمى،

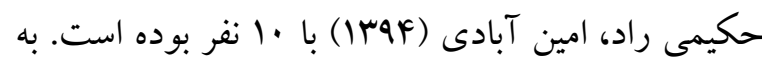
لحاظ منطقه جغر افيايى، شهرى كه بيشترين يُزوهش ها در زمينه مداخلات عصب روانشناختى را به خود اختصاص داده، شهر اصفهان بوده است.

بررسى تحليلى بثزوهشهاى مورد استفاده به تفكيك متغيرهاى مستقل و وابسته در جدول r ارائه شده است.
نتايج جدول ا نشان مىدهد كه بيشترين بيزوهشهاى انجام شده در حيطه مداخلات عصب روانشناختى بر بهبود عملكرد تحصيلى دانشآموزان با اختلالات ياد گيرى ويزه مربوط به مهرومومهاى 94-9F بوده است. مجموع حجم نمونه كل يثوهشها 990 بوده است؛ كه بيشترين حجم نمونه مربوط به ئزوهش هاى محمدى، اقبالى، متعالى، كريمى (94) و و اصلى آزاد و و

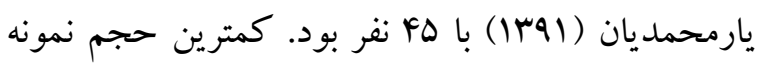

جدول r متغير هاى مستقل و وابسته در هريك از يخوهشها

\begin{tabular}{|c|c|c|c|c|c|}
\hline متغير وابسته & متغير وابسته & متغير وابسته & متغير مستقل دوم & متغير مستقل اول & ئزوهش \\
\hline عملكرد رياضى & حافظه كارى & اضطراب رياضى & - & مداخله يارانه يار حافظه كارى & 1 \\
\hline- & - & عملكرد تحصيلى & - & آموزش كاركردهاى اجرايى & $r$ \\
\hline - & - & تجبود عملكرد & - & آموزش حافظه فعال & $r$ \\
\hline- & - & عملكرد رياضى & روابط فضايى & آموزش فراشناخت & r \\
\hline - & - & عملكرد رياضى & - & مداخلات عصب روانشناختى & $\Delta$ \\
\hline- & - & كاهش غلطهاى & - & برنامهى تركيبى آموزش مستقيم و آكاهى واجناسى & 9 \\
\hline - & - & يِيشرفت تحصيلى & - & تقويت كاركردهاى اجرايى & r \\
\hline- & - & تو انايى حل مسئله & - & توانبخشى نوروسايكولوزيكى & $\wedge$ \\
\hline - & - & عملكرد رياضى & - & آموزش درك روابط فضايى & 9 \\
\hline & & عملكرد خواندن & & آموزش حافظه كارى & 1. \\
\hline - & ياد كيرى & حافظه & - & بازىهاى تو جهى & 11 \\
\hline- & - & عملكرد رياضى & - & آموزش توجه & ir \\
\hline- & - & عملكرد املا & - & كاربرد ياديارها & ir \\
\hline- & - & عملكرد رياضى & آموزش ادراك حسى - حركتى & برنامه آموزشى تقويت توجه & if \\
\hline- & - & 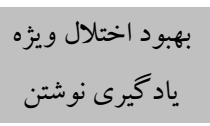 & روش تكرار و تمرين & روش كلينگهام-اورتون & 10 \\
\hline & & عملكرد حلمساله & - & تو انبخشىنوروسايكولوزيكى & 19 \\
\hline- & عملكرد درسى & كنش هاى اجرايى & - & درمان عصب روانشناختى & iv \\
\hline- & - & كاركرد رياضى & - & بازىهاى توجه افزا & 11 \\
\hline- & - & عملكرد املا & راهبردهاى تقويت ادراك ديدارى & راهبردهاى تقويت حافظه فعال & 19 \\
\hline- & - & عملكرد تحصيلى & - & مداخلات عصب روانشناختى & r. \\
\hline
\end{tabular}




\begin{tabular}{|c|c|c|c|c|c|}
\hline- & عملكرد تحصيلى & حافظه فعال & - & برنامه آموزش مهارتهاى توجه & rl \\
\hline- & - & اختلال ديكته & - & روش درمانى ادراكى حركتى كيارت & rr \\
\hline- & - & توانايى ديكته & - & آموزش دقت & rr \\
\hline - & - & 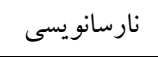 & - & روش جند حسى فرنالد & re \\
\hline
\end{tabular}

مهارت هاى عصب روانشناختى) بر متغير وابسته (عملكرد

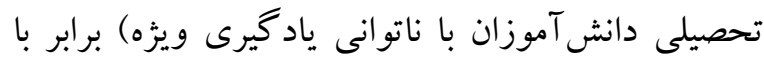
1/ه1 است كه بر اساس جدول تفسير اندازه اثر كوهن، زياد ارزيابى مىشود؛ بنابراين مىتوان كفت بر اساس نتايج اين بُزوهش مداخلات مبتنى بر مهارتهاى عصب

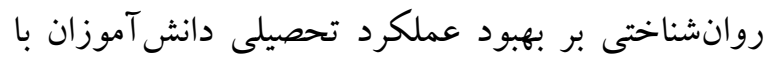
ناتوانى يادگيرى ويثه تأثير زيادى داشته است. همئنين سطح معنادارى تر كيبى ا +. • به دست آمد.
در اين بخش بر اساس دادهاى ارائه شده در گزارش هر يكك از ئزوهشهاى مورد نظر، به محاسبهى اندازه اثر

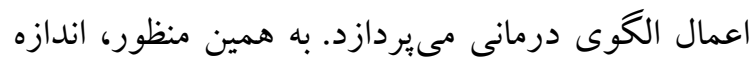
اثر طبق مراحل فراتحليل هويت و كرامر محاسبه شد (ترجمه پياشا شريفى وهمكاران، تحقيقات انجام شده ميزان تأثير مداخلات عصب روانشناختى بر بهبود عملكرد تحصيلى دانش آموزان با ناتوانى ياد گيرى ويزه مورد بررسى قرار گرفت. بر اساس

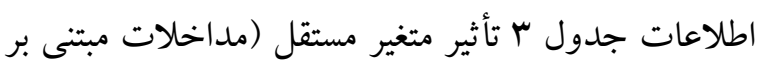

جهار مرحله محاسباتى فراتحليل به شرح زير است: مرحله ا- محاسبه ى اندازه اثر (مطالعات همبستكى) براى هر مطالعه مرئه

مر حله r- تبديل نمره r (مطالعات همبستخى) هر يثزوهش به d d هوهن (براى مطالعات آزمايشى) مرحله ب- تركيب اندازه اثر مطالعات آزمايشى به منظور محاسبه اندازه اثر كل

مرحله F- معنادارى مطالعات تركيب يافته

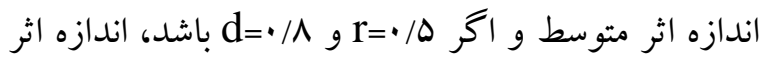
اندازه اثر نشان دهنده ميزان يا درجه حضور بديده در

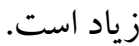
جامعه است. هرجه اندازه اثر بزرگكتر باشد، درجه حضور در جدول ب به بررسى تعداد جلسات مداخله در هر

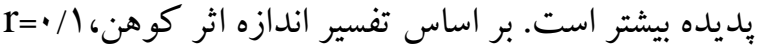
يزوهش و شاخصهاى آمارى فراتحليل شامل: نمرات

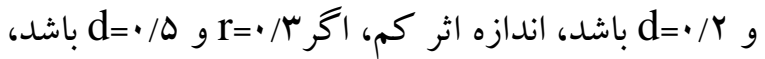

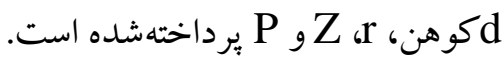


جدول ب اندازه اثر حاصل از اعمال متغير آزمايشى در ثزوهشهاى مورد نظر

\begin{tabular}{|c|c|c|c|c|c|c|}
\hline d & $\mathbf{R}$ & $\mathbf{Z}$ & $\mathbf{P}$ & تعداد جلسات & $\mathbf{N}$ & ئزوهش \\
\hline נr & - lOQF & $r / . q$. &.$/ \cdot 1$ & 10 & $\mu$. & 1 \\
\hline $1 / .9$ & $\cdot / F A \Lambda$ & $r / . q$. &.$/ . \cdot 1$ & 11 & f. & $r$ \\
\hline $1 / r \Delta$ & - /DqF & $r / . q$. & $\cdot / \cdot 1$ & 10 & $r$. & $r$ \\
\hline $1 / \cdot F$ & $\cdot / 44$ & $r / \cdot q$. & $\cdot / \cdot 1$ & rA & FD & $p$ \\
\hline $1 / r \Delta$ & $\cdot / \Delta G F$ & $r / \cdot q$. & $\cdot / \cdot 1$ & YF & $\mu$. & $\Delta$ \\
\hline$Y / r V$ & . & r/TYG & $\cdot / \cdot 1$ & f. & 1. & $q$ \\
\hline $1 / r \Delta$ & $\cdot$. lDGF & $r / \cdot q$. & $\cdot / \cdot 1$ & ir & $r$. & $\checkmark$ \\
\hline I/rY & . $/ \Delta r$ & T/MYG & $\cdot / \cdot 1$ & rI & r. & $\Lambda$ \\
\hline $1 / \wedge 1$ & $.19 V 9$ & r/viq & $\cdot / \cdots 1$ & ir & $\mu$. & 9 \\
\hline $1 / N 1$ & $.190 \mathrm{~V}$ & $r / V 19$ & $\cdot / \cdots \cdot 1$ & 11 & Hr & 1. \\
\hline I/rY & . $/ \Delta r$ & T/MYG & $\cdot / \cdot 1$ & 11 & $r$. & 11 \\
\hline $1 / r \Delta$ & $\cdot / \Delta q F$ & $p / . q$. & $\cdot / \cdot 1$ & ir & $\mu$. & ir \\
\hline 9/19 &.$/ 99$ & r/viq & $\cdot / \cdots 1$ & $\wedge$ & 10 & ir \\
\hline $1 / r \Delta$ & $\cdot / \Delta q F$ & $r / . q$. & $\cdot / \cdot 1$ & 1. & $\mu$. & if \\
\hline $1 / T r$ & $\cdot / \Delta \Delta F$ & r/viq & $\cdot / \cdots \Delta$ & $\wedge$ & FD & 10 \\
\hline $1 / 91$ & .199. & $r / . q$. &.$/ \cdot 1$ & ir & $r$. & 19 \\
\hline .191 & . MYFF & $Y / \cdot \Delta F$ & $\cdot / \cdot r$ & 10 & f. & IV \\
\hline $1 / Y Y$ & $\cdot / \Delta r$ & T/MYG & $\cdot / \cdot 1$ & if & $r \cdot$ & 11 \\
\hline$Y / Y V$ & $\cdot / V \Delta Q$ & r/viq & $\cdot / \cdots 1$ & 1. & rF & 19 \\
\hline $1 / 1 \Delta$ & $\cdot / \Delta q A$ & $r / . q$. & $\cdot / \cdot 1$ & 1. & $\mu$. & $r$. \\
\hline $1 / \cdot 1$ & $\cdot / F A \Lambda$ & $r / . q$. & $\cdot / \cdot 1$ & 1. & f. & rI \\
\hline $1 / r \Delta$ & - IDGF & $r / . q$. & $\cdot / \cdot 1$ & $\wedge$ & $\mu$. & $r r$ \\
\hline . $/ 94$ & . /FYF & Y/TYG & $\cdot / \cdot 1$ & 10 & $\mu$. & r \\
\hline$\cdot / v$ & ه מת/. & $1 / 940$ & $\cdot / \cdot \Delta$ & 1. & YF & $r p$ \\
\hline
\end{tabular}

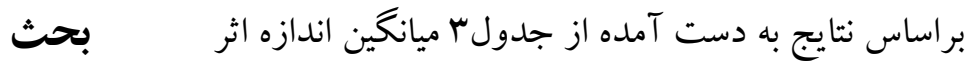
فراتحليل با يكِيارجه كردن نتايج حاصل از يُزوهشهاى

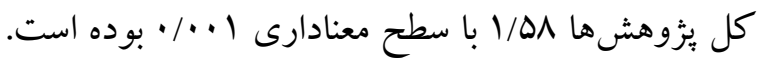
مختلف، كه روى نمونهاى متعددى اجرا شدهاند، بيشترين اندازه اثر مربوط به يزوهش ا...بيگدلى، نجفى، ديدگاه جامع ترى از اثر متغيرهاى مختلف به دست

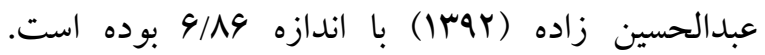
مىدهد، در واقع با در كنار هم قرار دادن نتايج حاصل از بيشترين تعداد جلسه مداخلات كزارش شده ·F جلسه و

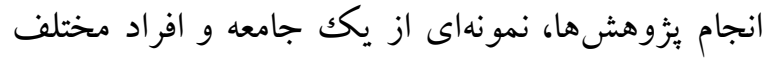
كمترين ^ 1 جلسه بوده است. را مورد بررسى قرار مىدهد. جنين يافتهايى در 
محمدى و كريمى (94) (1)، بيرامى، موحدى و انصارى (4)(1)، اخوان تفتى، رباط جزى و هاشمى (1M94) است.

از ميان YF يثوهش مورد بررسى، بيشترين ميزان اندازه اثر مربوط به ئزوش ا...بيخدلى، نجفى، عبدالحسين زاده (IrqY) با اندازه اثر 9/A9 بوده است كه كاربرد ياديارها در آموزش املا به كودكان داراى اختلال ياد كيرى املا را مورد يُزوهش قرار دادند. همجنين يُوهش هاى نيكو

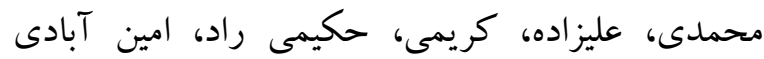

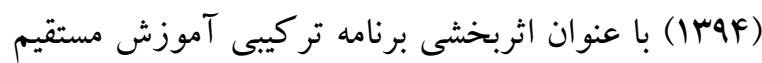
و آكاهى واج شناسى بر كاهش غلطهاى املايى در

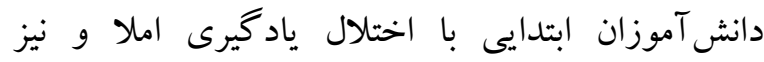
يثزوهش بإيرزاده (IraF) با عنوان اثربخشى راهبردهاى تقويت حافظه فعال و ادراكك ديدارى بر بهبود عملكرد املا در د دانشآموزان با ناتوانى يادگيرى با اندازه اثر(Y/YV) بالاترين اندازه اثر را در بين بثوهش به خود

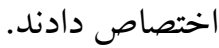

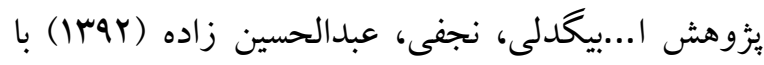
يافتهاى بثزوهش بيشين از جمله مانالو، اوساكا، ساكيتانى (Y/Y) ياديارها در بهبود مشكلات ديكته نويسى دانش آموزان داراى اختلال ديكته تأثير مثبت و معنادار دارد. در تبيين اين مىتوان گفت، دو علت مهم اختلالهاى يادگيرى املا اشكال در حافظهى ديدارى و حافظهى شنيدارى كودكان است (لرنربr..r)، بنابراين در آموزش املا به اين كودكان بايد تدابيرى اتخاذ شود كه به بهبود

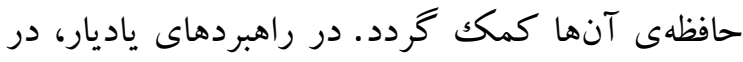
واقع بين اشياء يا كلمهها از طريق ايجاد يكك رابطهى ذهنى بين آنها ارتباط معنادارى ايجاد مىشود (مانالو،
جوامعى جون جامعه ايران كه گوناكونى بيشترى را دارد مهم تر است، جرا كه اين گوناگونى، تفاوتهاى بيشترى را به همراه دارد و به ناجار بايد اطلاعات متعددى را از نمونههاى مختلف اين جامعه، در دست داشت تا با يكهارجه كردن اين اطلاعات، شباهتها را به دست آورد و با تفاوتها به طرز مناسبى برخورد كرد. به بيانى ديخر

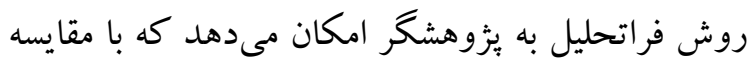
يخوهش ها با يكك روش، به شناختى بيشتر از بديدهها

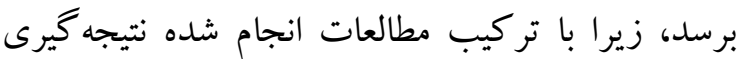

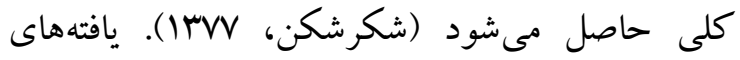
حاصل از اين فراتحليل نشان داد كه مداخلات روانشناختى و آموزشى بر بهبود عملكرد تحصيلى دانشآموزان داراى اختلال يادگيرى رئى رياضى تأثير زيادى(d=1/DN) دارد. يافتهاى اين فراتحليل تأييدى بر برخى :ثزوهشهاى قبلى از جمله هونجانى (Y) (1)،

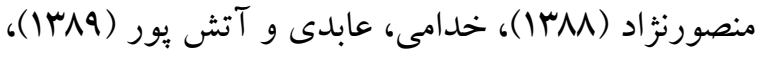

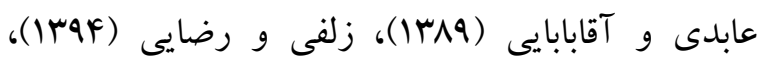

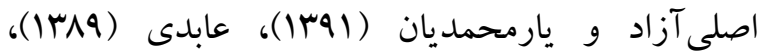

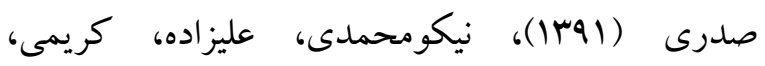

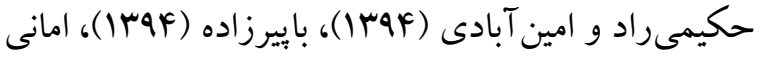

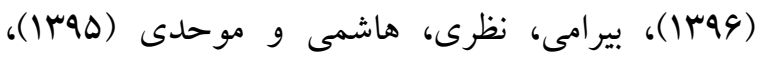
اصلى آزاد، عابدى و يارمحمديان (سوسا)، بخشايش،

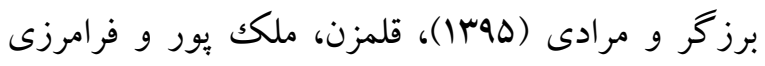

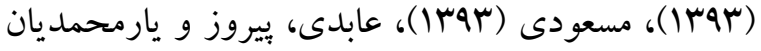

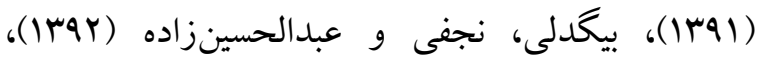

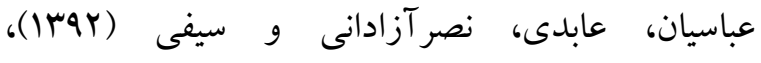

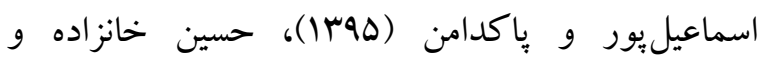
همكاران (هوب(1)، دهقانى، افشين و كيخسروانى (هوس (I)، ابراهيمى (هوب())، محمود بور (ه (هب))، محمدى، اقبالى، 
دست يابد كه اين امر به نوبه خود، بهبود مهارت املا را

$$
\text { در بي دارد (كندى و فلن، ب... (Y). }
$$

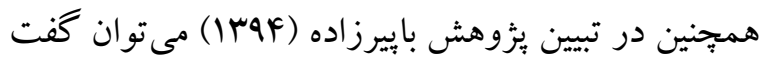
وجود نقص در ادراكك ديدارى و حافظه فعال در كودكان داراى ناتوانى يادگيرى، مىتواند دليل اساسى

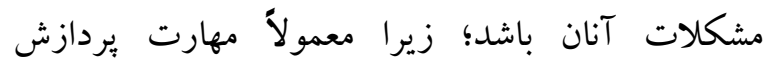
اطلاعات بينايى براى بررسى و درك شكل و نيز نمادهاى بينايى نظير حروف و اعداد استفاده مىشود كه اساس بازشناسى كلمات در سالهاى دبستان بر پِيايه همين مهارتها است. اين مهارتها آنقدر با اهميت است كه له بـ ضعف و به نوعى اختلال در آنها موجب بروز مشكلاتى در خواندن، نوشتن و املا مىشود. لذا تقويت حافظه فعال و ادراكك ديدارى مى تواند بخشى وسيعى از مشكلات اين كود كان را برطرف نمايد.

\section{نتيجه كيرى}

توجه به زمينهاى فرهنگ دئى در جوامع مختلف، مى تواند در اثربخشى رويكردهاى گوناكون درمانى مؤثر باشد. يكى از ويز كىهاى بارز فراتحليل اين است كه امكان

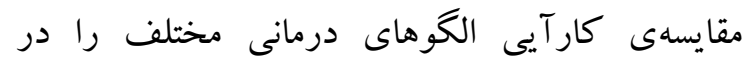
بافتهاى فرهنگى مختلف فراهم مى كند. به هر حال، به

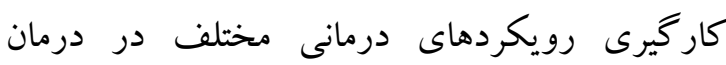
مشكلات امرى بديهى است؛ اما آن جه بهتر است مورد توجه قرار گيرد، ميزان موفقيت اعمال الكوى مورد نظر در رفع مشكل مطرح شده است. در اين فراتحليل سعى

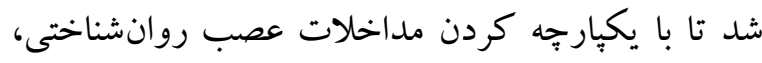
ميزان موفقيت اين الكو مورد بررسى قرار گيرد. اما تنها بررسى يكك الخوى درمانى و مقايسهى آن با عدم درمان، كافى نيست و بهتر است كه با انجام مطالعه در زمينه ساير

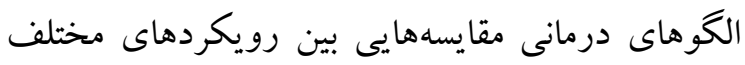

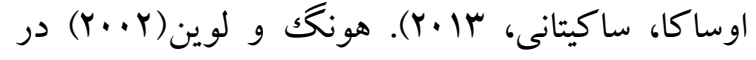
يثزوهشى با استفاده از ياديارهاى كلامى و كلمههاى كد، نشان داده شد كه آزمودنىهايى كه از ياديارها استفاده مى كنند، در يادآورى عملكردى بهتر از گروه كنترل دارند و در مقايسه با گروه كنترل ميزان فراموشى كاهش بيدا مى كند. همبِنين اين يُّوهش هماهنگك با ساير

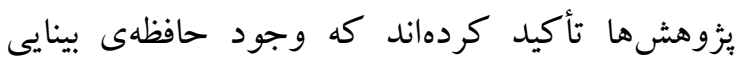
مناسب، يكك بيش نياز ضرورى براى هجى كردن

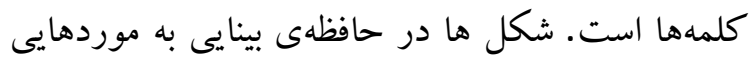
مربوط مىشود كه براى يكك واج جندنويسه وجود دارد. از نظر هالاهان و كافمن (ترجمه جواديان، ایمبا) براى بهبود عملكرد حافظهى دانش آموزان داراى اختلالهاى ياد گيرى، مى توان از راهبردهاى ياديار استفاده كرد. اين راهبردها روشهايى هستند كه با استفاده از نمادهاى ديدارى يا صوتى توانايى حافظه، مهارتهاى بازيابى را افزايش مىدهند. منطق استفاده از ياديارها اين است كه

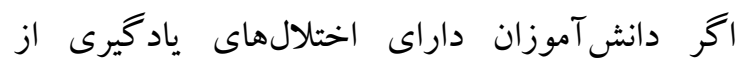

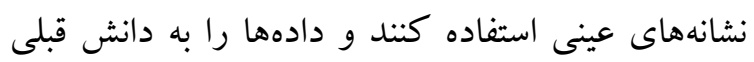
ارتباط دهند، آن دادهها را بهتر به ياد مى آورند. ياديارها، موضوعهاى نآشنا را آشناتر، دادههاى بىمعنا را معنادار و دادههاى انتزاعى راعينى تر مى كند. در تبيين اثربخشى بالاى يزوهش نيكو محمدى، عليزاده، كريمى، حكيمى راد، امين آبادى (TوM آموزش تر كيبى و آكاهى واج شناختى، توانايى شنيدن، دست كارى كوجّكترين واحد صدا و تعويض واج است. ازاينرو، آموزش خرده توانايىهاى آكاهى واجشناختى سبب بالا رفتن مهارت واجشناختى مىشود و فرد مىتواند به آكاهى در مورد ساختار واجى و زبان 
of students with dyscalculia. Joumal of Learning Disabilities, 6(3), 30-52. (In Persian)

Amani M. (2017). Effect of strengthening executive functions on the academic achievement in the children with nonverbal leaming disabilities. Middle Eastem. Joumal of Disability Studies, 7(2), 42-52. (In Persian)

Asliazad M, Abedi A \& Yarmohammadian A. (2015). The effectiveness of spatial relations perception training on the mathematics performance of boy students with math learning disability. Psychology of Exceptional Individuals, 5(17), 113-131.(In Persian)

Asli-Azad M, Yarmohammadian A. (2012). The effect of metacognition training and perception of spatial relationship on improvement of mathematical operation in children with mathematics learning disabilities. Joumal of Clinical Psychology, 4(2), 61-70. (In Persian)

Bacon M, Parmentier B, Barr P. (2013). Visuospatial memory in dyslexia: Evidence for strategic deficits. Memory, 21(2), 189-209.

Bakhshayesh A, Barzegar K, Moradi Ajani V. (2016). The effect of working memory training on reading performance of boy's students with leaming disability. Psychology of Exceptional Individuals, 6(22), 96-110. (In Persian)

Bapirzadeh E. (2015). The effectiveness of active memory enhancement strategies and visual perception on spelling performance improvement in students with learning disabilities. Ministry of Science, Research and Technology. University of Guilan. Faculty of Literature and Humanities. (In Persian)

Bayrami M, Movahedi Y, Ansari S. (2018). The effectiveness of neuropsychological rehabilitation treatment on the performance of problem solving in patients with disabilities leam math. Shenakht Joumal of Psychology \& Psychiatry, 4(4), 24-33. (In Persian)

Bayrami M, Nazari M, Hashemi T, Movahedi Y. (2017). The effectiveness of neuropsychological rehabilitation treatment on the performance of problem solving in patients with math learning disabilities. Iranian Joumal

$$
\begin{aligned}
& \text { صورت كيرد تا ميزان تأثير و موفقيت هر يكك از اين } \\
& \text { الكوها نسبت به عدم درمان و نسبت به يكديخر، بيشتر } \\
& \text { مشخص شود. بر اساس اين يافتهاست كه درمانكران } \\
& \text { مىتوانند با توجه به حيطهى تخصصى خود، الكوهاى سوري } \\
& \text { درمانى متناسب با مشكلات مورد مواجهه را، علمىتر } \\
& \text { انتخاب و اجرا كنند و به نتايج بهتر و مطمئنترى دست } \\
& \text { يابند. در نهايت بيشنهاد مىشود تا از تكرار موضوعات } \\
& \text { مختلف استقبال شود تا نمونهاى بيشترى از جامعه مورد } \\
& \text { نظر بررسى شود و با در كنار هم قرار دادن نتايج حاصل } \\
& \text { از نمونه هاى مختلف، ديد بهترى نسبت به واقعيت جامعه } \\
& \text { در دسترس قرار گيرد. همجنين اميد مىرود با تأكيدهايى } \\
& \text { مبنى بر لزوم گزارش كامل آمارههاى يارهاى، گزارش } \\
& \text { نسبتاً دقيق، سطح معنادارى، بر آورد اندازه اثر و همجرنين } \\
& \text { با رواج روزافزون رويكرد فراتحليل، حساسيت در جاب } \\
& \text { كامل و دقيق يافته ها افزايش يابد. } \\
& \text { سياسگزارى } \\
& \text { در پايان از تمامى كسانى كه ما را در انجام هر جّه بهتر } \\
& \text { اين يثوهش همراهى كردند تشكر و قدردانى مى كنيم. }
\end{aligned}
$$

\section{References}

Abedi A, Agha-babaie S. (2010). The effectiveness of working memory training on improving the academic performance of children with dyscalculia. Journal of Clinical Psychology, 2(4), 73-81. (In Persian)

Abedi A, Pirooz Zijerdi M \& Yarmohammadian A. (2012). The effectiveness of training attention on mathematical performance of students with mathematics learning disability. Joumal of Learning Disabilities, 2(1), 92-106. (In Persian) AkhavanTafti M, RobatJazi F \& Hashemi Z. (2017). Examining the effect of attention-increasing games on the math performance and attention 
of Rehabilitation Research in Nursing, 3(2), 6167. (In Persian)

Bigdeli E, Najafy M, Abdol hosseinzadeh A. (2014). Effectiveness of the application of mnemonics in dictation instruction for children with dictation leaming disorders. Joumal of Learning Disabilities, 3(2), 6-20. (In Persian)

Cappa C, Giulivi S, Schilinò A, Bastiani L, Muzio C, Meloni F. (2015). A screening on specific leaming disorders in an Italian speaking high genetic homogeneity area. Research in Developmental Disabilities, 45, 329-342.

Comoldi C, Di Caprio R, De Francesco G, \& Toffalini E. (2019). The discrepancy between verbal and visuoperceptual IQ in children with a specific learning disorder. An analysis of 1624 cases. Research in Developmental Disabilities, 87,6472.

Crane N, Zusho A, Ding Y, Cancelli A. (2017). Domain-specific metacognitive calibration in children with learning disabilities. Contemporary Educational Psychology, 50, 72-79.

Dehghani Y, Afshin A, Keykhosrovani M. (2017). Effectiveness of neuropsychological therapy on executive functions and educational performance of students with dyscalculia. Quarterly Journal of Child Mental Health, 3(4), 14-25. (In Persian)

Fletcher J, Lyon G, Fuchs L, Bames M. (2018). Learning disabilities: From identification to intervention. Guilford Publications.

Foster A, Titheradge H, \& Morton J. (2015). Genetics of leaming disability. Paediatrics and Child Health, 25(10), 450-457.

Garcia V, Pereira L, Fukuda Y. (2007). Selective attention's performance in children with leaming disabilities. Joumal Otorhinolaryngol, 73(3):404-11.

Ghalamzan S, Malekpour M, Faramarzi S. (2015). Effectiveness of attention-oriented games on memory performance and learning of preschool children with learning neuropsychological disabilities. Joumal of Clinical and Personality Psychology. 2 (11):310. (In Persian)
Honjani I. (2007). The effectiveness of precision education on dictation ability of students with leaming disabilities in elementary schools in Isfahan. Ministry of Science, Research and Technology. Master's thesis in Psychology, Psychology, University of Esfahan. Faculty of Education and Psychology. (In Persian)

Hoseinkhanzadeh A, Shojaee S, Amiri P, Sadeghi S, Azadimanesh P, Azadimanesh S. (2017). The effect of attention strengthen and perception of sensory-motor training program on mathematical performance of male students with mathematical learning disability. Joumal of Cognitive Learning Strategies, 4(7), 139156.

Hulme C, Snowling M. (2016). Reading disorders and dyslexia. Current opinion in pediatrics, 28(6), 731.

Hwang Y, Levin J. (2002). Examination of middleschool students' independent use of a complex mnemonic system. Joumal of Experimental Education, 71(1), 25-38.

javanmard G, Asadollahifam S. (2017). Comparison of executive functions of mathematical learning disabled in children with reading, writing learning disabled and normal children. Neuropsychology, 3(10), 39-50. (In Persian)

Kennedy E, Flynn M. (2003). Training phonological awareness skills in children with Down Syndrome. Research in Developmental Disabilities, 24(1), 44-57.

Khodami N, Abedi A, Atashpour H. (2010). The effectiveness of executive function training on improvement academic performance of students with mathematical learning disabilities. Joumal of New Findings in Psychology, 5(17), 63-77. (In Persian)

Lerner J. (2003). Leaming disabilities: theories, diagnosis and teaching strategies. Boston: Houghton Mifflin.

Mahmoodpour A. (2016). Comparison of the effectiveness of attention skills training program on active memory and academic performance of two groups of students with specific leaming disorders. Islamic Azad 
University. Central Tehran Branch. Faculty of Educational Sciences and Psychology. (In Persian)

Manalo E, Uesaka Y, Sekitani K. (2013). Using mnemonic images and explicit sound contrasting to help Japanese children learn English alphabet sounds. Joumal of Applied Research in Memory and Cognition, 2(4), 216-221.

Mansournejad Z. (2009). The effectiveness of Fernald's multi-sensory approach to improving immediate and inadequate writing among students in secondary schools in Kashan. Ministry of Science, Research and Technology - University of Isfahan. Faculty of Educational Sciences and Psychology. Master's Thesis in Exceptional. Child Psychology. University of Esfahan. (In Persian)

Massoudi M. (2014). The effectiveness of Kepart's perceptual-motor therapy on dictation disorder on students in elementary schools in Shiraz. Islamic Azad University of Marvdasht. Faculty of Psychology and Educational Sciences. (In Persian)

Mirmehdi, R, Shojaei F. (2016). Evaluating and comparing neuropsychological skills profile in normal students, students with specific leaming disorder and attention deficit hyperactivity students. Neuropsychology, 2(6), 91-106. (In Persian)

Mizen L, Cooper S. (2012). Leaming disabilities. Medicine, 40(11), 619-622.

Mohammadi F, Eghbali A, Motaali L, Karimi S. (2014). The comparison between the effectiveness of two methods, GillinghamOrton and Practice-Repetition, on improvement of elementary students with dysgraphia. Educational and School Studies, 3(3), 99-117.(In Persian)

Momeni Shahraki F, Malekpour M, Abedi A, Faramarzi S. (2018). Comparison of the efficiency of neuropsychological and Davis method interventions on reading performance of dyslexic of first and second grade elementary students. Neuropsychology, 4(12), 153-174. (In Persian)

Nelson M, Burns M, Kanive R, Ysseldyke J. (2013). Comparison of a math fact rehearsal and a mnemonic strategy approach for improving math fact fluency. Joumal of School Psychology, 51(6), 659-667.

Nevo E, Breznitz Z. (2011). Assessment of working memory components at 6 years of as predictors of reading achievements a year later. Journal Experimental child psychology, 109(1), 73-90.

Nikomohammadi N, Alizadeh H, Karimi B, Hakimirad E, Aminabadi Z. (2015). The effectiveness of combined training program (direct instruction and phonological awareness) in spelling errors among elementary students with spelling learning disorder.Joumal of Modem Psychological Researches, 10(39), 189-204. (In Persian)

Rahbar Karbasdehi E, Abolghasemi A, Hossein Khanzadeh A, Rahbar Karbasdehi F. (2019). Comparison of neurocognitive and social skills students with and without dyscalculia. Neuropsychology, 4(15), 107122. (In Persian)

Sadri S. (2011). The effect of psychological neurological interventions on academic performance of female students with mathematical leaming disabilities in secondary elementary schools in Isfahan. Ministry of Science, Research and Technology. Payame Noor University of Tehran - Faculty of Humanities. (In Persian)

Thorell LB, Lindqvist S, Bergman Nutley S, Bohlin G, Klingberg T. (2009). Training and transfer effects of executive functions in preschool children. Developmental science, 12(1):10613.

Zare H, Ahmadi Azghandi A, Noferesti A, Hosseinaei A. (2012). The effect of metacognitive instruction of problem solving on mathematical learning disability. Joumal of Learning Disabilities, 2(2), 40-58. (In Persian)

Zolfi W, Rezaei A. (2015). The effect of working memory computer assisted intervention on 
1f. اعظم رشيدى و همكاران

mathematics anxiety, working memory and performance mathematics among students with mathematics learning disabilities. Joumal of Instruction and Evaluation, 8(30), 75-86. (In Persian) 